\title{
Blended learning: Deficits and prospects in higher education
}

\author{
Liliana Cuesta Medina \\ Universidad de La Sabana
}

\begin{abstract}
This article examines the nature and evolution of the term blended learning (BL), which encompasses numerous connotations, including its conception as a strategy, delivery mode, opportunity, educational shift, or pedagogical approach. Although much has been said in this field, very few studies examine the different types of blends behind their implementation. To address this gap in the literature, the article indicates types of blends and analyses the characteristics of BL, its benefits and limitations, supported by a review of literature, and an analysis of a sample of BL cases in higher education language-teaching worldwide. Additional data were also gathered through a questionnaire administered to language department chairs. Data were triangulated and analysed using the grounded theory approach. The article closes with an examination of different levels of blending, the various perspectives within the educational community on its use, and a discussion of its future applicability, especially in higher education.
\end{abstract}

\section{Introduction}

This study arises out of the consideration that blended learning (BL) environments offer a highly individualised and self-managed language-learning experience for the university student, as well as the widely-accepted understanding that integrating both modalities (e-learning and face-to-face learning) ensures flexibility of access to and use of knowledge. Furthermore, such a blend offers the combination of varied social interaction patterns in a synchronous/asynchronous scenario that meets different needs and learning styles. This integration provides benefits for students including program cost reductions, improved time efficiency, and locational convenience (Brown, 2003; Ho, Lu, \& Thurmaier, 2006), as well as a highly customisable experience for the digitally literate (and non-literate) learners. As argued by Owston, York, and Murtha (2013), BL should accommodate different types of learners and ensure pedagogical alternatives to help learners achieve enhanced academic success. Thus, offering students the opportunity to fit multiple commitments within their schedules while simultaneously feeling engaged with a course is a positive predictor for a successful BL experience. However, teachers and educational institutions are not always ready to respond to such circumstances and conditions, due to either their lack of knowledge and experience in the field or to their lack of awareness concerning the efficient structuring of BL initiatives. Very often, institutions launch BL projects without considering how blends should be made or how a smooth integration between academic and administrative aspects may be best achieved. This article presents important implications for those interested in the development of BL plans to support students' needs effectively.

\section{The origins of $\mathrm{BL}$}

BL is a term that lacks a unified definition. Generally speaking, its conceptualisation involves the addition of information and communication technologies (ICTs), in combination with different instructional delivery modes, to traditional learning methods, though in practice it may identify a somewhat haphazard mixing and matching of different learning delivery modes (De George-Walker \& Keeffe, 2010). Nevertheless, current definitions of BL tend to address three commonly related aspects of instruction and learning (Graham, 2006): a blend of online and face-to-face (F2F) instruction (Reay, 2001; Rooney, 2003; Sands, 2002; Ward \& LaBranche, 2003; Young, 2002), a blend of instructional methods (Driscoll, 2002; House, 2002; Rossett, 2002), and a blend of instructional modalities (or delivery media) (Bersin \& Associates, 2003; Orey, 2002; Thomson, 2002). Graham (2006) conceives of BL as a system that combines F2F instruction with computer-mediated instruction and fosters not only the use of different information and communication technologies but also facilitates the emergence and development of different kinds of interactions and encounters among participants.

BL also represents “a fundamental shift in instructional strategy” (Watson, 2008, p. 6) and its flexibility enables the online delivery of content to be combined with the best features of classroom interaction and live instruction to personalise learning, encourage thoughtful reflection, and individualise instruction across a diverse group of learners. Several generally applicable characteristics of this approach are presented in 
the discussion that follows to provide the reader with a broader view of the features and implications that underlie BL.

BL does not mean bolting technology onto a traditional course and/or using technology as an add-on to teach a difficult concept or deliver supplemental information. BL should be viewed as an opportunity to redesign the way that courses are developed, scheduled, and delivered in higher education through a combination of physical and virtual instruction, that is bricks and clicks (Bleed, 2001). BL also surpasses barriers of time and place and can have a direct positive influence on students' learning outcomes when compared with traditional teaching (Chen \& Jones, 2007; Melton, Bland, \& Chopak-Foss, 2009), though several researchers have observed that this latter characteristic depends heavily on student satisfaction with the development and completion of the course (Chang \& Fisher, 2001). Thus, student satisfaction is one of the factors that can be gauged to determine whether BL has been effective or not (Holland, Kaplan, \& Sams, 1995; Kintu \& Zhu, 2016; Rienties \& Toetenel, 2016; Shantakumari \& Sajith, 2015; Waheed, Kaur, \& Kumar, 2016).

BL fosters higher levels of interaction between learner and instructor, between learner and learner, between learner and content, and between learner and course interface (Hewitt, 2003; Moore, 1989; Sutton, 2001; Wagner, 1997). Alvarez and Cuesta (2012) suggest that an adequate analysis and implementation of these interactional modes should aim at providing students with the opportunity to customise their learning experiences according to their needs, styles, skills, demographics, previous learning history with online formats, and beliefs. Consequently, interaction outcomes should favour satisfaction, participation, communication, exploration, and self-regulation processes (Cuesta Medina, 2010; Palmer \& Holt, 2014; Rourke, Anderson, Garrison, \& Archer, 1999; Vrellis, Avouris, \& Mikropoulos, 2016; Wagner, 1997).

BL fuses both the online and the F2F world by mixing the socialisation opportunities of the F2F classroom with the technologically assisted learning possibilities of the online environment (Dziuban, Hartman, \& Moskal, 2004; Wilson, 2010). BL, as an approach, can be an effective and low-risk strategy for meeting the challenge of the transformational changes that technological developments bring to higher education (Garrison \& Kanuka, 2004). Through BL, students can develop different abilities to find, use, and evaluate information ethically and effectively (Chartered Institute of Library and Information Professionals [CILIP], n.d.). Therefore, some of the pedagogical implications regarding BL programs are related to the design and implementation of inquiry-based learning activities through unrestricted interaction and critical discourse, which fosters more critical and creative learners (University of Calgary, 2016). Successful BL requires a well-devised plan that must include a theoretically sound instructional model, high-quality faculty development, course development assistance, learner support systems, and on-going formative and summative assessment plans (Bonk, Kim, \& Zeng, 2006; Dziuban et al., 2004).

In this paper, BL is viewed as a pedagogical approach that offers educational communities the opportunity to customise their learning using synchronous and asynchronous delivery modes to increase levels of interaction among the agents involved (generally, students and faculty). Therefore, the synergy between instructional and training models and/or processes to implement successful BL initiatives must evolve, not only to prepare students to satisfy their personal learning needs but also to foster academic community outreach and guarantee high quality standards in rich and flexible scenarios.

\section{Characteristics}

Before examining the different blends and varieties that blended courses/programs may have, it is important to discuss the different positions that have been taken regarding the what and why of blending. Those dealing with BL should be well acquainted with the rationales underpinning the blend and the expected outcomes of the fusion. Graham (2009) presents a typology of blended models and argues that BL can occur at four levels: the activity level, the course level, the program level, or the institutional level. He points out that "the nature of the blends is [generally] determined by the designer or instructor" (p. 11), this being predominant at the course and activity levels rather than at the institutional and program ones, where academic administrators may control the decision-making process.

Blending at the activity level occurs when the blend contains a learning activity that is composed of both F2F (face-to-face) and computer-mediated elements. As mentioned previously, the role of the designer is very important in this type of blend as they will be the one who selects and sequences the combination of 
pedagogical and technological components (e.g., mixed reality, computer-mediated communication [CMC], mobile technologies) to create an authentic learning experience.

Blending at the course level is regarded as one of the most common ways to blend and involves the combination of a F2F component with computer-mediated activities. There are two commonly used blended options. The first includes learning activities that use computer-mediated and F2F sections that overlap in time. The second separates the learning activities in different time blocks that are structured chronologically but do not necessarily overlap. In this respect, Masie (2002) illustrates further flexible combinations, such as a "blend of simulations and structured courses, managerial coaching with e-learning activities and onthe job training with brown bag informal sessions” (p. 59). She refers to two highly flexible course/class configurations. The first is designed to enable students to take a class at different times during the day. According to her, the "actual sessions of a multi-day class are offered synchronously or asynchronously, so that students who cannot attend all sessions can still keep up with the flow of the course” (p. 60). The second kind of configuration is less instructor-oriented and fosters the creation of communities of practice among learners from the beginning of, and indeed throughout the course, thereby providing learners with added support and peer-learning opportunities.

Blending at the program level is more typical at higher education (degree) levels (Graham, Allen, \& Ure, 2005). The corresponding models of this blend are: participants choose a mix between F2F courses and online courses, or the course offerings (composed of F2F and online courses) are prearranged by the program. There are numerous degree programs in which students take specified courses on campus and the remainder online.

\section{Methods}

The present study used a qualitative, inductive, research design with all appropriate ethical concerns taken into consideration to comply with the norms and standards of the field. Data was collected using two instruments: an evaluation rubric for institutional BL resources, and an online questionnaire directed to deans and researchers in language and technology departments at accredited universities offering BL programs. The primary objective for both instruments was to collect data on the structures of blended language-teaching courses/programs, with a focus on three important areas: (1) the various institutions definitions of BL, (2) the type of blend, and (3) the types of resources used to support learning.

The evaluation rubric for institutional BL resources was applied through a systematic web-based search that examined the sites of 18 universities across different continents. In accordance with the tenets of criterion sampling (Patton, 1990), only universities accredited by their countries' corresponding boards/ministries of education were included in the search. Only publicly available online data found within the selected university web sites were considered.

The online questionnaire was distributed to 30 people, 12 of whom responded. The researcher made contact with university faculty by e-mail to invite them to complete the questionnaire, access to which was provided through Google Docs (http://docs.google.com/), a web-based service that can be used for survey design and distribution. Each invitee who responded to the questionnaire provided their informed consent as a participant in the study. Besides the previously mentioned objective pertaining to both instruments, the questionnaire had the added goals of gathering data on the perceived benefits and challenges of implementing a BL program in the different institutions surveyed, as well as the strategies used to address those challenges. The questionnaire also collected data on participants' perceptions regarding which aspects of BL programs most warrant attention if future offerings are to be improved.

Data from both instruments (an evaluation rubric for institutional BL resources and online questionnaire) were triangulated and analysed using the grounded theory approach (Corbin \& Strauss, 2008). Data coding and triangulation led to the identification of four main categories: types of blends, reported benefits, support sources used, and experienced difficulties. All these categories relate to critical aspects that should be considered when planning and developing effective BL courses and programs.

\section{Results}

\section{Types of blends}


The results of the web-based search recorded in the evaluation rubric revealed data on institutional BL resources of varying detail and quality. In some cases, information was readily available about the content of the BL courses offered, but less so regarding the types of blends. Such information might well be included in departmental/internal documents, but it was not yet available to the public via the internet. Nevertheless, records of resources available to support education without many access restrictions were found. Some of the most interesting and relevant cases are described in this section.

Within Europe, five institutions were analysed: the Open University (UK), the Universidad Nacional de Educación a Distancia UNED (Spain), the University of Cambridge (UK), the University of Southampton (UK), and the University of Trento (Italy). The first four of these universities reported no information on the types of blends, though the University of Trento's web site indicated that their BL courses included one classroom-based lesson per week (or three lessons per week for their intensive courses), for a total of 36 academic hours (or 27 effective classroom hours) at the B1 level, and 33 academic hours (or 25 effective classroom hours) for the B2 level (Common European Framework of Reference for Languages).

Within North and Latin America, nine institutions were analysed: Monmouth University (USA), the University of Florida (USA), the University of Southern California (USA), the Universidad Nacional de Colombia (Colombia), the Universidad de La Sabana (Colombia), the Universidad de Guadalajara Virtual (Mexico), the University of Illinois at Chicago (USA), the University of Calgary (Canada), and Athabasca University (Canada). Again, none of these institutions provided information on the types of blends, with the exception of the University of Illinois, which indicated that 25-74\% of instruction in their blended programs and courses occurred online.

In Australia, two institutions were included in the analysis: Macquarie University, and the University of New South Wales. Only Macquarie University provided information on their courses blended delivery mode held on campus. They had separate streams based on enrolment, in which students chose how to engage with the unit. Students enrolling in the external mode could listen to iLecture recordings and participate in online activities. It was designed with largely online materials and optional on-campus sessions. Regardless of their enrolment mode, students had the option to choose whether to attend oncampus sessions and participate as a single cohort in online learning activities.

Finally, the analysis included two universities from the Asian sphere: the Open University (Malaysia), and Waseda University (Japan). Both universities shared access to their BL delivery modes. At the Open University, self-managed learning was fostered, especially through purpose-designed modules. These included three to five F2F tutorials/seminars or F2F sessions where learners and tutors met regularly at a common venue (learning centre) at scheduled times. Direct and indirect teaching strategies were exercised. At Waseda University, two blended formats were offered for commuting students: full on-demand lessons, and combined used of on-demand lessons. All lessons were given in a full on-demand format (without designated days or lesson periods), a format in which some sessions are held in classrooms, such as guidance sessions or examinations. The combined use of on-demand lessons includes both classroom lessons and on-demand lessons. There is a designated day and lesson period for classroom lessons, and various formats are used, including holding on-demand lessons at random a few times only, holding alternate classroom lessons and on-demand lessons every 15 days, or distributing on-demand content as revision material for classroom lessons. Waseda University was also notable for the high level of ondemand lessons used even by campus-based students and for the large number of combined on-demand lessons (a mix of classroom and on-demand lessons) in addition to its use of full on-demand lessons.

\section{Reported benefits}

The most salient considerations derived from the triangulation and analysis of both data sets suggest that the main benefits of implementing a BL program can include the possibility of offering learners additional, carefully designed, and varied learning materials, available at any time and place (flexibility feature) with the aim of enhancing their learning practices and achieving specific learning objectives through the support of a medium (E. Huber, personal communication, 04 August, 2012). Thus, BL is seen as a digital literacy strategy that supports student and staff development, and that enables students to take advantage of resources, not only at a technological level but also at a pedagogical one, namely in reference to communitybuilding and collaborative learning opportunities (E. Huber, personal communication, 04 August, 2012). 
All of the questionnaire respondents identified certain key components that they felt could help ensure success in the implementation of blended learning. These related to support, continuous professional development, personalisation and flexibility, in both the delivery and the assessment domains.

Personalisation should be considered at various stages in BL projects, but perhaps most particularly at the materials design and implementation phases. This component has an important relationship with student satisfaction, success, and quality in any BL program. In the results from the evaluation rubric for institutional BL resources collected through the web search, it was evident that all the surveyed institutions favour the use of different blends, mainly at course and/or program levels, and generally, institutions offer flexible tutoring modes as well as on-campus sessions. Some universities have their own F2F centres (regional and/or national) and some also offer residential schools as additional options for knowledge access. Additionally, there is a strong tendency for institutions to manage content and units/lessons asynchronously. Not all the institutions surveyed offered real-time online session components (synchronous instructor lectures).

Likewise, some universities had separate specialised areas and/or distance education units that administered all blended/virtual courses/programs and supported professional development courses for faculty and staff in the area of BL. However, most of the institutions assigned this responsibility to individual faculties/departments, where it seems staff managed these courses and/or programs. Some institutions required proctored exams in their courses and/or programs, administered either on or off campus. Some universities also offered student advisers and study facilities in their own region.

\section{Support sources used}

In terms of support sources to aid BL, the analysis suggests that all the surveyed universities contracted online course management systems, the most widely used being Blackboard Learn (http://www.blackboard.com/learning-management-system/blackboard-learn.aspx) and Moodle (https://moodle.com/). All the surveyed universities offered students a variety of communication services (mainly e-mail and chats with instructors) as well as, in most cases, other services such as online social networks, informal study groups, clubs, and academic events. Only a few universities made use of SecondLife (http://secondlife.com) to administer course content and live lectures. Very few universities reported the usage of removable-disc based English language software (e.g., on CD-ROMs), while all institutions favoured the use of web authoring tools and open-access systems. (See Appendix A for a report on technology support sources used in each university.)

Results also showed that the surveyed institutions, which included some the world's leaders in online, blended, and distance learning (e.g., Athabasca, Macquarie, the Open University [UK]) have highly robust systems in place and a focus on training their staff to develop and support blended learning initiatives successfully, often with a complete team of specialists at their service (e.g., Athabasca, Calgary, Macquarie, the Open University [UK], University of New South Wales/College of Fine Arts).

\section{Difficulties experienced}

One of the principal challenges of implementing a BL program reported by the surveyed deans and researchers was making students aware of the online materials that are available as part of their learning program — that is marketing (J. Watson, personal communication, $18 \mathrm{July,} \mathrm{2012)} \mathrm{—as} \mathrm{well} \mathrm{as} \mathrm{training} \mathrm{them}$ (and the staff) in the use of online materials and effective approaches to autonomous learning. The linkage between existing and/or traditional curricula must be made explicit and constantly monitored to ensure institutional success. Respondents also emphasised key aspects for success: maintaining appropriate technical access and online materials, and ensuring that the online learning spaces and materials are pedagogically sound. Huber (personal communication, 4 August, 2012) observes that if there is no control over the learning spaces, it is very difficult to design a true BL course and, therefore, to make appropriate use of the learning space. To have a human resource infrastructure and training plan sequenced within an appropriate timeframe not only enables the attainment of the goals set but also facilitates interdisciplinary work amongst units/programs. It also helps the personnel involved stay abreast of training initiatives and related processes, so that these plans are always included in the improvement programs of the blended project. 
Many of the surveyed deans and researchers also signalled that various initiatives had been launched in their respective contexts to address the limitations described above. Many of these initiatives could readily be adapted for use in other institutions that face similar difficulties in the implementation of their BL programs. Such initiatives usually included information, dissemination, and demonstration plans in the forms of posters or similar publicity materials that introduced students to BL processes and resources in their first F2F class sessions. These kinds of strategies tie into the idea of customising materials according to learner needs and institutional pedagogies. Watson characterises such actions as simply a matter of maximising the use of the available resources: "we make our own materials mostly with our own tool[s] and pedagogic[al] approach” (personal communication, 18 July, 2012). Along with recommendations for the regular updating of materials and spaces (sites) and the provision of guidelines about accessing and using these (amongst other strategies for ongoing technical support), the surveyed deans and researchers also emphasised the need for careful planning and adjustment of student and faculty workloads. Respondents from Macquarie University discussed the implementation of a faculty partnership program in their context whereby faculty and instructional designers, working on unit development together, were able to produce outcomes in a relatively short (approximately 6-month) timeframe.

The surveyed deans and researchers also discussed how higher education stakeholders (i.e., agents who exert leadership and enforce decision-making processes) could improve the quality of future BL programs. All of those surveyed concurred on the importance of strengthening the rationale of planning BL programs, carefully putting pedagogy first and technology second, fostering effective curriculum alignment by looking at assessment across a program, and ensuring that all curriculum components (e.g., content, activities, materials, competences) align smoothly with the learning outcomes planned. Similarly, aspects such as learner and faculty professional development programs, implementing efficient and user-friendly technologies, and enhancing teaching related research were also referenced. Thus, stakeholders play a leading role in educational and financial integration matters that can ultimately benefit educational communities pursuing BL projects; therefore, their actions should align with properly regulated strategies, supporting the development of a suitable environment for excellence.

\section{The road ahead}

The remaining discussion in this paper expands upon the preceding analysis of the results with a focus on the typology represented in Moore (2004), which examines the implications of blending from various perspectives: institutional administrations, learners, teachers, student services, and information technology. These perspectives are further analysed and contrasted in different blended situations by outlining a number of benefits and challenges involved in the design, development, and implementation of blended programs, from learner, teacher, and administrative perspectives, as an attempt to foster effective instructional design decisions that benefit the target BL population and assist educational agents in overcoming the obstacles on the path towards success.

\section{Learners' perspective}

Drawing on the premise that BL courses are gaining prominence globally and complement rather than replace traditional forms of tertiary learning (Organisation for Economic Co-operation and Development [OECD], 2005), numerous studies have examined how BL fuses with instructional and motivational processes that have a direct influence on students' learning performance. Mitchell and Forer (2010) reported a marked increase in levels of student flexibility and choice towards the BL program implemented, observing that students acknowledged learning could occur in multiple contexts, supplemented by valuable points of physical contact. They also noted benefits from the BL program on students' perspectives on or behaviour toward approaching learning, where ready access to resources seemed to correlate with confidence, learning, and the use of technologies. The results of the present study also reinforce the value of the essential features of effective blends: flexibility (in terms of curricular adaptations and delivery modes), personalisation (in terms of both human and technical resources available to learners), support for stakeholders, and professional development for faculty. Such results moreover support the development of learned-centred BL models that encourage learner engagement and cater to various educational modes by opening possibilities for students to control their own learning rather than leaving decisions to instructors (Hofmann, 2006). 
Various studies have reported that BL designs contribute to improved learning outcomes for students (Dziuban, Shea, \& Arbaugh, 2005; Twigg, 2003). Early in 2002, qualitative research studies carried out at the University of Wisconsin in Milwaukee (Aycock, Garnham, \& Kaleta, 2002) also suggested that students learn more in blended courses than they do in comparable traditional class sections. Teachers responsible for the blended sections report that students wrote better papers, performed better on exams, produced higher quality projects, and were capable of more meaningful discussions on course material. Positive findings have also been reported by Dahlstrom, Walker, and Dziuban (2013), who found that students are willing to use their mobile devices for academic activities as they acknowledge their need for continued guidance in academic applications that go beyond what occurs in the classroom. Even more, special attention is paid to adopt measures that can optimise in-class time through flipped models, with the aim of freeing class time from lecturing by expanding knowledge opportunities, broadening learning, and facilitating greater teacher-to-student mentoring, peer-to-peer collaboration, and cross disciplinary connections (Roehl, Reddy, \& Shannon, 2013).

Guidance and support mechanisms for BL need to be carefully examined and implemented. Depending on the nature of the BL program, the blend needs to incorporate methods and resources that enrich the learning process effectively. Whether the choices include self-access tutorials (mediated by digital communications technologies) and/or synchronous or asynchronous tutorials, both faculty and students need to understand the rationales for the available choices and the procedures agreed for implementing them efficiently if these are not to become burdens but remain efficient resources for learner development. Such tutorials must be planned strategically, such that factors of purpose, time and pending commitments are taken into consideration. Studies such as Moore and Gilmartin's (2010) have argued that tutorials integrated into blended courses (delivered both synchronously and asynchronously) can be of great value to students, directly influencing their decision-making processes and fostering a constructive alignment between all elements of a course. They also note that "the incentivization of attendance and participation was the salient factor in promoting better engagement and attendance” (2010, p. 337), reporting a high rate of student attendance to tutorials (the focuses of which were closely related to course assignments). Moreover Moore and Gilmartin (2010) cite the importance of the instructors' assessment strategies as being purposefully designed to encourage the less intrinsically motivated students to participate in tutorials and engage with the learning materials. In general, tutorials have proven an effective strategy for coordinating engagement with course/program content for both learners and instructors (Medina, 2009).

\section{Teachers' perspective}

In BL systems, learners are provided with different sets of components to pick and choose (Sethy, 2008) and enhance their academic experience. Given that the blended system offers instructional flexibility (via F2F, online instructor-led activities, web-based self-access activities) by using a practical, up-to-date, and time-effective complement to their lessons, instructors can also reduce classroom lecture time by addressing class-related issues via audio-visual means. Thus, the integration of media sources (such as video, podcasts, and web-casts) in a blended lesson facilitates the use of multiple means to produce and deliver content, and optimise time and cost benefits.

By using BL systems, students can self-discover pathways to self-directed learning because they are exposed to multiple options to access and produce content both synchronously and asynchronously, with or without the assistance of an instructor. Thus, instructors should scaffold participants to better accommodate their learning styles, times, and skills, and ensure task completion of the program/course/module requirements in the learners' scheduled time. In this regard, Hocutt (2001) has argued that all components in a BL system should be appropriately interrelated and the corresponding transitions between them should be smooth. Hocutt further recommends that there should be "consistency among the components in terms of message, language and style, and sufficient and appropriate redundancy among the components” (2001, p. 6). Following Sethy's (2008) proposals, instructors and administrators designing a BL system should ensure that it:

- $\quad$ promotes connections and conversations,

- $\quad$ guides, directs, and tracks learning routes,

- $\quad$ nurtures a world-class global workforce,

- $\quad$ provides consistent and updated messages,

- $\quad$ utilises the technologies efficiently, 
- $\quad$ fosters independent habits for learning and reference,

- $\quad$ encourages learning and work, and

- $\quad$ improves performance and control costs.

Therefore, faculty and staff need to ensure that BL design appropriately integrates F2F and online components and strategies (Çakıroğlu, 2014), deciding what content could be learned as well or better online and what technologies would best support that content learning (Moore, 2004). Thus, in agreement with Kineo and The Oxford Group (2013), the relative complexity of introducing blended solutions and a lack of internal expertise remain significant challenges in the field. As seen in the preceding analysis of data from the systematic web-based search, only a few institutions were equipped with the infrastructure needed to create special training units aided by groups of specialists from various disciplines to support BL programs. This study also revealed that at present, many faculty and staff members still act intuitively when adapting F2F content to online/blended learning delivery modes, a fact that should prompt remedial actions by educational agents to ensure an efficacious and strategic transformation and blend.

Various studies have examined faculty satisfaction in the online teaching and learning environment including enhanced interaction with students, increased student engagement in learning, flexibility of the teaching and learning environment, opportunities for continuous improvement, institutional support, professional recognition, personal rewards, and effective institutional management of change (Aycock et al., 2002; Dziuban et al., 2005; Hofmann, 2006; Vaughan, 2007). Additionally, the present study draws attention to two additional factors that affect faculty satisfaction with and teachers' perceived effectiveness of a given blend. The first factor concerns the pedagogical value of the units, learning spaces and materials, which should be soundly designed, selected and delivered in accordance with target learner needs and the institution's pedagogical approach, keeping in mind appropriate strategic assessment measures and the underlying conditions to align curricular goals across a course or program. The second factor concerns the interdisciplinary joint ventures and/or partnerships, through which faculty, instructional designers, developers, and researchers apply methods from their fields of expertise to enrich the content, communication, design, development and evaluation of both teaching and learning experiences in a BL program. Such interdisciplinary ventures offer a myriad of learning experiences for students and faculty, promoting more natural and logical connections that cut across subject-matter areas and thereby better address the needs of users, stakeholders and the wider educational community itself. Such integrative approaches should also pursue the negotiation of knowledges and practices (from design to delivery stages) toward a more robust understanding of learners' expected outcomes, performances, and, overall, of the academic structures and pedagogical approaches that underlie the BL course or program.

\section{Institutional perspective}

Naturally, to prepare optimal blends, agents require support from their large-scale stakeholders. Moore (2004) argues that faculty productivity, along with student and faculty satisfaction, may increase where university administrations provide adequate funding, high quality training in pedagogy and technology, and support for disciplinary research and publication related to online and blended environments. Such increased productivity would then, in turn, enhance an institution's reputation (Twigg, 2003), thereby expanding access to its educational offerings, and potentially reducing operating costs (Vaughan, 2007). Yet successful and innovative transformations of this sort can be only be realised where there is institutional support for analysing program expectations and their impact on the institution itself. From an institutional perspective, stakeholders need to plan appropriate strategies and tactics to ensure that decisions are taken and executed effectively throughout the lifecycle of a BL project, as well as to react with agility and efficiency in instances where conflict, resistance and difficulties with the attainment of objectives arise.

Several studies have reported that BL is as much a route for the contemporary on-campus student as for off-campus students, since both groups have similar needs for flexibility. Indeed, BL is more than a passing educational fashion (Bonk et al., 2006), rather, it is an effective learning option for both school and workplace settings. For precisely this reason, institutions must urgently seek better ways to ensure academic quality in their BL courses or programs and prevent drop-outs by designing retention programs that help ensure smooth academic pathways for students. As Tinto (2009) and West et al. (2016) argue, universities must recognise that the roots of student attrition are dependent on not only students' contexts and specific life situations but also on the conditions of the educational settings in which students are expected to learn. 
Additionally, cost-reduction strategies, mainly represented by off-campus faculty work, reduction in space requirements, and use of resources, must also be aspects that any institution should consider prior to launching BL initiatives. According to Twigg (2003), cost reduction options could aim either at increasing student enrolments with little or no change in course expenditures or at maintaining existing student enrolment levels while reducing the instructional resource costs for courses. Nevertheless, though it is obvious that online/blended courses still require faculty, instructors and students would not necessarily meet on campus with a specific schedule (if at all). Such situations represent opportunities to reduce capacity and time constraints, as well as the costs of hiring qualified instructors to sometimes remote campus locations. Similarly, the residential campus model implies inclusion of a wide array of additional non-academic fees into admission and course/program prices, including for recreational facilities, athletics, entertainment, insurance, and computer and laboratories services. If institutions have a large off-campus population, they may consider an alternative fee schedule for online students to reflect their limited use of some services and facilities. However, extensive planning and service allocation plans should be carefully analysed to ensure the needs of the target population are met and a smooth fusion of administrative, academic, and institutional philosophies.

\section{Concluding remarks}

The current generation of students (ranging from school to university years) is very well equipped with digital devices (Zawacki-Richter, Müskens, Krause, Alturki, \& Aldraiweesh, 2015) and indeed views information technologies as essential elements of their lives, due to increasing mobility, always-on availability, and still-increasing value for communication. Though networked opportunities are still limited in many regions, teachers and students must learn to integrate these in increasingly blended classroomswhich reflect an increasingly blended world. Effective blended learning must become more personalised, flexible, and on-demand if it is to serve as a support source-as a means to an end - that expands the scope of traditional instructional and learning actions while simultaneously fostering independent and lifelong learning skills and the practical uses of technology. Once the selection of the blend and specific allocations concerning instructional design, target learning outcomes, and required infrastructure are made, the contents and processes in BL can be fine-tuned to provide more solid grounds for developing the blended learning initiative. However, even then, a myriad of challenges remains, including the need for constant support and training for faculty and learners.

Thus, all blended programs program should provide facilities for faculty to acquire new teaching skills (e.g., facilitating online interactions and assessing students), to develop technology skills, to plan or redesign target learning activities that match course objectives and outcomes. Failure to do so can result in unfocused course offerings, the mere replication of traditional F2F approaches (Vaughan, 2007), or in the rejection of the integration of technology into educational settings by instructors and students. Additionally, further research should focus on examining how such blends and trainings can best be made and how aspects like an appropriate facilitator-student ratio may be most effectively planned and maintained. Mbati and Minnaar (2015) identify this issue as one of the biggest concerns in online education, given that there are frequently large numbers of students per facilitator, though this problem seems very frequently ignored by educational stakeholders. If current learners (often referred to as millennials or digital natives) are to be offered efficient online learning environment opportunities, regardless of their economic, social, linguistic, or disability backgrounds, educational systems must strive to meet their needs and preferences. At the same time, however, instructional content, processes, and policies must be designed to equip learners with the knowledge, skills, and potential to be critical, innovative and competitive in the future labour force.

The results of the present study validate many previously recognised features of effective BL, but also highlight the importance of learned-centred approaches, which lie in a triad where the perspectives of teachers, institutions, and learners themselves converge. Ranging from matters of guidance and support mechanisms (integrating the pedagogical underpinnings of the blend) to those of assessment and interdisciplinary strategies (nurtured by content and area partnerships), these results demonstrate the need for integrative approaches that support more effective BL outcomes.

The issues discussed in this article might offer diverse teaching and learning horizons to support teachers and learners, both in an immediate, mid- or long-term future. Furthermore, understanding the implications of selecting a particular type of blend for use in the target BL environment would not only ease implementation but would also help learners develop throughout their learning experiences. Not only do 
learners require training in the use of the necessary technologies but they also need accompaniment by faculty and staff who are themselves sufficiently equipped to design and develop high quality BL programs that are cost-effective, flexible, and accreditable within the worldwide higher education community. However, before launching any BL plan, a preliminary needs analysis to assess the potential benefits and risks of implementing a BL approach should be conducted. Such a needs analysis should ideally be carried out by an interdisciplinary team (composed of course instructors, designers, technical support teams, administrative and educational stakeholders) that assesses issues ranging from those of infrastructure to human resource availability. The results of such an analysis would provide a firm evidential base for subsequent actions. Likewise, an appropriate monitoring and assessment strategy would be needed as an iterative process, successively modified and expanded over time, depending on the needs, target outcomes, and feedback loops between the different stages of implementation.

With this paper, I hope to have opened inquiry and debate about how blends should be made in different educational contexts, keeping in mind that there should always be a rationale to blend what learners, instructors, and institutions need, desire, and can possibly afford, with the ultimate aim of putting technology in the service of education and development. In part, the results of the present study align with emphases found in previous work on BL regarding the potential benefits for learners in terms of customising the learning experience and potential benefits for institutions in terms of cost reductions and increased accessibility. However, the present study's results also highlight areas that merit more attention than they have received in the past. For one thing, there remains a mismatch between theory and practice, in that the actual design and implementation of BL programs and courses does not always comply with what are recognised as ideal best practices. In particular, it seems that BL implementations are often deficient in terms of the type of blend chosen, the articulation between components in the blend, and the sequencing of these components. Finally, the complexity of both designing and delivering BL courses or programs, as well as of the kinds of content demanded by twenty-first century student needs, is often insufficiently appreciated, and there is an urgent requirement for greater interdisciplinary coordination amongst institutional staff and faculty in the implementation and maintenance of BL initiatives. Further research on these issues would do much to consolidate the considerable, but still in many ways largely unrealised, potential of BL.

\section{References}

Alvarez, C., \& Cuesta, L. (2012). Designing for online interaction: Scaffolded and collaborative interventions in a graduate-level blended course. The EUROCALL Review, 20(1), 5-12. Retrieved from http://eurocall.webs.upv.es/index.php?m=menu_00\&n=news_20_1

Aycock, A., Garnham, C., \& Kaleta, R. (2002). Lessons learnt from the hybrid course project. Teaching with Technology Today, 8(6), 1-6. Retrieved from https://www.wisconsin.edu/systemwideit/teaching-with-technology-today/

Bersin \& Associates. (2003). Blended learning: What works? An industry study of the strategy, implementation, and impact of blended learning. Oakland, CA: Bersin \& Associates.

Bleed, R. (2001). A hybrid campus for the new millennium. EDUCAUSE Review, 36(1), 16-24. Retrieved from https://net.educause.edu/ir/library/pdf/erm0110.pdf

Bonk, C. J., Kim, K.-J., \& Zeng, T. (2006). Future directions of blended learning in higher education and workplace learning settings. In C. J. Bonk, \& C. R. Graham (Eds.), Handbook of blended learning: Global perspectives, local designs (pp. 550-567). San Francisco, CA: Pfeiffer.

Brown, R. (2003). Blending learning: Rich experiences from a rich picture. Training and Development in Australia, 30(3), 14-17.

Çakıroğlu, Ü. (2014). Analyzing the effect of learning styles and study habits of distance learners on learning performances: A case of an introductory programming course. International Review of Research in Open \& Distance Learning, 15(4), 161-184. https://doi.org/10.19173/irrodl.v15i4.1840

Chang, V., \& Fisher, D. (2001). The validation and application of a new learning environment instrument to evaluate online learning in higher education. Proceedings of the Australian Association for Research in Education AARE Annual Conference, Fremantle, 1-16. Retrieved from http://www.aare.edu.au/data/publications/2001/cha01098.pdf

Chartered Institute of Library and Information Professionals (n.d.). Policy and advocacy - Information literacy: Definition. Retrieved from http://www.informationliteracy.org.uk/definitions/definitions-ofil/\#squelch-taas-accordion-shortcode-content-0 
Chen, C. C., \& Jones, K. T. (2007). Blended-learning vs. traditional classroom settings: Analyzing students' satisfaction with inputs and learning processes in an MBA accounting course. In B. N. Schwartz \& A. H. Catanach (Eds.), Advances in Accounting Education: Vol. 8. Teaching and curriculum innovations (pp. 25-37). Bingley, UK: Emerald. https://doi.org/10.1016/S1085$\underline{\text { 4622(07)08002-9 }}$

Corbin, J., \& Strauss, A. (2008). Basics of qualitative research: Techniques and procedures for developing grounded theory (3rd ed.). Thousand Oaks, CA: Sage.

Cuesta Medina, L. (2010, August). Metacognitive instructional strategies: A study of e-learners' selfregulation. Paper presented at the Fourteenth International CALL Conference: Motivation and Beyond, University of Antwerp, Antwerp, Belgium. Retrieved from http://uahost.uantwerpen.be/linguapolis/scuati/proceedings_CALL 2010.pdf

Dahlstrom, E., Walker, J. D. D., Dziuban, C., \& Morgan, G. (2013). ECAR study of undergraduate students and information technology, 2013. Retrieved from https://net.educause.edu/ir/library/pdf/ERS1302/ERS1302.pdf

De George-Walker, L., \& Keeffe, M. (2010). Self-determined blended learning: a case study of blended learning design. Higher Education Research \& Development, 29(1), 1-13. https://doi.org/10.1080/07294360903277380

Driscoll, M. (2002). Blended learning: Let's get beyond the hype. Retrieved from https://www07.ibm.com/services/pdf/blended_learning.pdf

Dziuban, C. D., Hartman, J. L., \& Moskal, P. D. (2004). Blended learning. Educause Center for Applied Research Research Bulletin, 7, 1-12. Retrieved from https://net.educause.edu/ir/library/pdf/ERB0407.pdf

Dziuban, C. D., Shea, P., \& Arbaugh, J. B. (2005). Faculty roles and satisfaction in asynchronous learning networks. In S. R. Hiltz \& R. Goldman (Eds.), Learning together online: Research on asynchronous learning networks (pp. 169-190). Mahwah, NJ: Lawrence Erlbaum Associates.

Garrison, D. R., \& Kanuka, H. (2004). Blended learning: Uncovering its transformative potential in higher education. Internet and Higher Education, 7(2), 95-105. https://doi.org/10.1016/j.iheduc.2004.02.001

Graham, C. R. (2006). Blended learning systems: Definition, current trends, and future directions. In C. J. Bonk, \& C. R. Graham (Eds.), Handbook of blended learning: Global perspectives, local designs (pp. 3-21). San Francisco, CA: Pfeiffer.

Graham, C. R. (2009). Blended learning models. In M. Khosrow-Pour (Ed.), Encyclopedia of Information Science and Technology (2nd ed., pp. 375-382). Hershey, PA: IGI Global. https://doi.org/10.4018/978-1-60566-026-4.ch063

Graham, C. R., Allen, S., \& Ure, D. (2005). Benefits and challenges of blended learning environments. In M. Khosrow-Pour (Ed.), Encyclopedia of information science and technology (pp. 253-259). Hershey, PA: IGI Global. https://doi.org/10.4018/978-1-59140-553-5.ch047

Hewitt, J. (2003). How habitual online practices affect the development of asynchronous discussion threads. Journal of Educational Computing, 28(1), 31-45. https://doi.org/10.2190/PMG8-A05JCUH1-DK14

Ho, A., Lu, L., \& Thurmaier, K. (2006). Testing the reluctant professor's hypothesis: Evaluating a blended-learning approach to distance education. Journal of Public Affairs Education, 12(1), 81-102. Retrieved from http://media.netpub.net/clientnet/pdf_files/JPAE\%20Vol12_No1.pdf

Hocutt, R. (2001). The second e-learning wave. Training Magazine, 38(9), 96.

Hofmann, J. (2006). Why blended learning hasn’t (yet) fulfilled its promises: Answers to those questions that keep you up at night. In C. Bonk \& C. Graham (Eds.), Handbook of blended learning: Global perspectives, local designs (pp. 27-40). San Francisco, CA: Pfeiffer.

Holland, M., Kaplan, J. D., \& Sams, M. R. (1995). Intelligent language tutors: Theory shaping technology. Hillsdale, NJ: Erlbaum.

House, R. (2002, January 8). Clocking in column. The Spokesman-Review. Retrieved from https://www.highbeam.com/doc/1G1-120631369.html

Kineo, \& The Oxford Group. (2013). Blended learning: Current use, challenges and best practices. Brighton. Retrieved from https://www.kineo.com/m/0/blended-learning-report-202013.pdf

Kintu, M. J., \& Zhu, C. (2016). Student characteristics and learning outcomes in a blended learning environment intervention in a Ugandan university. Electronic Journal of E-Learning, 14(3), 181-195. Retrieved from http://www.ejel.org/volume14/issue3/p181

Masie, E. (2002). Blended learning: The magic is in the mix. In A. Rossett (Ed.), The ASTD e-learning handbook (pp. 58-63). New York, NY: McGraw-Hill. 
Mbati, L., \& Minnaar, A. (2015). Guidelines towards the facilitation of interactive online learning programmes in higher education. The International Review of Research in Open and Distributed Learning, 16(2), 272-287. https://doi.org/10.19173/irrodl.v16i2.2019

Medina, R. (2009). Interaction in online tutoring sessions: An opportunity to knit English language learning in a blended program. PROFILE: Issues in Teachers' Professional Development, 11(2), 117134. Retrieved from http://www.revistas.unal.edu.co/index.php/profile/article/view/11446/36799

Melton, B. F., Bland, H. W., \& Chopak-Foss, J. (2009). Achievement and satisfaction in blended learning versus traditional general health course designs. International Journal for the Scholarship of Teaching and Learning, 3(1), 1-13. https://doi.org/10.20429/ijsotl.2009.030126

Mitchell, P., \& Forer, P. (2010). Blended learning: The perceptions of first-year geography students. Journal of Geography in Higher Education, 34(1), 77-89. https://doi.org/10.1080/03098260902982484

Moore, J. C. (Ed.) (2004). ALN principles for blended environments: A collaboration. Newburyport, MA: The Sloan Consortium. Retrieved from http://www.immagic.com/eLibrary/ARCHIVES/GENERAL/SLOANCUS/S041110C.pdf

Moore, M. G. (1989). Editorial: Three types of interaction. American Journal of Distance Education, 3(2), 1-7. https://doi.org/10.1080/08923648909526659

Moore, N., \& Gilmartin, M. (2010). Teaching for better learning: A blended learning pilot project with first-year geography undergraduates. Journal of Geography in Higher Education, 34(3), 327-344. https://doi.org/10.1080/03098265.2010.501552

Orey, M. (2002). Definitions of blended learning. Retrieved from http://morey.coe.uga.edu/

Organisation for Economic Co-operation and Development. (2005). E-learning in tertiary education (Policy Brief December 2005). Retrieved from http://www.oecd.org/edu/ceri/35991871.pdf

Owston, R., York, D., \& Murtha, S. (2013). Student perceptions and achievement in a university blended learning strategic initiative. Internet and Higher Education, 18, 38-46. https://doi.org/10.1016/j.iheduc.2012.12.003

Palmer, S., \& Holt, D. (2014). Development of student and academic staff perceptions of the elements of an online learning environment over time. Australasian Journal of Educational Technology, 30(4), 375-389. https://doi.org/10.14742/ajet.581

Patton, M. Q. (1990). Qualitative evaluation and research methods. Beverly Hills, CA: Sage.

Reay, J. (2001). Blended learning: A fusion for the future. Knowledge Management Review, 4(3), 1-6.

Rienties, B., \& Toetenel, L. (2016). The impact of learning design on student behaviour, satisfaction and performance: A cross-institutional comparison across 151 modules. Computers in Human Behavior, 60, 333-341. https://doi.org/10.1016/j.chb.2016.02.074

Roehl, A., Reddy, S. L., \& Shannon, G. J. (2013). The flipped classroom: An opportunity to engage millennial students through active learning strategies. Journal of Family \& Consumer Sciences, 105(2), 44-49. https://doi.org/10.14307/JFCS105.2.12

Rooney, J. (2003). Blending learning opportunities to enhance educational programming and meetings. Association Management, 55(5), 26-32.

Rossett, A. (2002). The ASTD e-learning handbook: Best practices, strategies, and case studies for an emerging field. New York, NY: McGraw-Hill.

Rourke, L., Anderson, T., Garrison, D. R., \& Archer, W. (1999). Assessing social presence in asynchronous test-based computer conferencing. Journal of Distance Education, 14(3), 51-70.

Sands, P. (2002). Inside outside, upside downside: Strategies for connecting online and face-to-face instruction in hybrid courses. Teaching with Technology Today, 8(6). Retrieved from http://www.uwsa.edu/ttt/articles/sands2.htm

Sethy, S. S. (2008). Distance education in the age of globalization: An overwhelming desire towards blended learning. Turkish Online Journal of Distance Education, 9(3), 29-44. Retrieved from http://tojde.anadolu.edu.tr/search.html

Shantakumari, N., \& Sajith, P. (2015). Blended learning: The student viewpoint. Annals of Medical and Health Sciences Research, 5(5), 323-328. Retrieved from https://www.ncbi.nlm.nih.gov/pmc/articles/PMC4594344/

Sutton, L. A. (2001). The principle of vicarious interaction in computer-mediated communications. International Journal of Educational Telecommunications, 7(3), 223-242. Retrieved from https://www.learntechlib.org/p/9534

Thomson. (2002). Thomson job impact study: The next generation of corporate learning. Stamford, CT: Thomson. Retrieved from http://mdavidmerrill.com/Papers/ThompsonJobImpact.pdf

Tinto, V. (2009, February). Taking student retention seriously: Rethinking the first year of university. 
Paper presented at the ALTC FYE Curriculum Design Symposium, Queensland University of Technology, Brisbane, Australia.

Twigg, C. A. (2003). Improving learning and reducing costs: New models for online learning. Educause Review, 38(5), 28-38. Retrieved from http://er.educause.edu/ /media/files/articledownloads/erm0352.pdf

University of Calgary (2016). Continuing education. Retrieved from http://conted.ucalgary.ca/elearn/

Vaughan, N. (2007). Perspectives on blended learning in higher education. International Journal on ELearning, 6(1), 81-94.

Vrellis, I., Avouris, N., \& Mikropoulos, T. A. (2016). Learning outcome, presence and satisfaction from a science activity in Second Life. Australasian Journal of Educational Technology, 32(1), 59-77. https://doi.org/10.14742/ajet.2164

Wagner, E. D. (1997). Interactivity: From agents to outcomes. New Directions for Teaching and Learning, 71, 19-26. https://doi.org/10.1002/tl.7103

Waheed, M., Kaur, K., \& Kumar, S. (2016). What role does knowledge quality play in online students' satisfaction, learning and loyalty? An empirical investigation in an eLearning context. Journal of Computer Assisted Learning, 32(6), 561-575. https://doi.org/10.1111/jcal.12153

Ward, J., \& LaBranche, G. A. (2003). Blended learning: The convergence of e-learning and meetings. Franchising World, 35(4), 22-23.

Watson, J. (2008). Blended learning: The convergence of online and face-to-face education. North American Council for Online Learning. Vienna, VA. Retrieved from http://files.eric.ed.gov/fulltext/ED509636.pdf

West, D., Huijser, H., Heath, D., Lizzio, A., Toohey, D., Miles, C., Searle, B., \& Bronnimann, J. (2016). Higher education teachers' experiences with learning analytics in relation to student retention. Australasian Journal of Educational Technology, 32(5), 48-60. https://doi.org/10.14742/ajet.3435

Wilson, J. (2010). Information smoothies: Embedding information skills in assessed learning. Assessment, Teaching \& Learning Journal, 9, 30-33. Retrieved from http://eprints.leedsbeckett.ac.uk/1032/

Young, J. R. (2002, March 22). "Hybrid” teaching seeks to end the divide between traditional and online instruction. The Chronicle of Higher Education. Retrieved from http://www.chronicle.com/article/Hybrid-Teaching-Seeks-to-End/18487

Zawacki-Richter, O., Müskens, W., Krause, U., Alturki, U., \& Aldraiweesh, A. (2015). Student media usage patterns and non-traditional learning in higher education. International Review of Research in Open and Distributed Learning, 16(2), 136-170. https://doi.org/10.19173/irrodl.v18i2.2806

Corresponding author: Liliana Cuesta Medina, liliana.cuesta@unisabana.edu.co

Australasian Journal of Educational Technology (c) 2018.

Please cite as: Cuesta Medina, L. (2018). Blended learning: Deficits and prospects in higher education. Australasian Journal of Educational Technology, 34(1), 42-56. https://doi.org/10.14742/ajet.3100 


\section{Appendix A Blended learning cases}

Table A1

European blended learning cases: Support sources used in BL

\begin{tabular}{|l|l|}
\hline University & Resources \\
\hline $\begin{array}{l}\text { The Open } \\
\text { University, }\end{array}$ & $\begin{array}{l}\text { OpenLearn (free educational content available to the community), live chat, e- } \\
\text { mail and online conferencing systems, online social networks, informal study } \\
\text { groups and events, web-based materials, national and regional centres, F2F or } \\
\text { online tutorials or day schools, residential schools (for some degrees), online } \\
\text { free courses, audio visual materials, community discussions via online forums. }\end{array}$ \\
\hline $\begin{array}{l}\text { UNED } \\
\text { Spain }\end{array}$ & $\begin{array}{l}\text { Virtual courses (platform-based), proctored exams, printed, audio-visual and } \\
\text { multimedia materials, web conferencing, virtual learning communities, on-site } \\
\text { assistance from professor-tutors at the associate centres, resource centres. }\end{array}$ \\
\hline $\begin{array}{l}\text { University of } \\
\text { Uambridge, }\end{array}$ & $\begin{array}{l}\text { Face-to-face workshops, online modules, and online seminars that run in real } \\
\text { time (webinars). Language centre online, live satellite television, off-air } \\
\text { recordings, John Trim Centre audio and video resources, help desks, local } \\
\text { computer officers, online resources and tutorials. }\end{array}$ \\
\hline $\begin{array}{l}\text { University of } \\
\text { Southampton, } \\
\text { UK }\end{array}$ & $\begin{array}{l}\text { MOOCs, online repositories, iTunesU, materials bank, collections, databases, } \\
\text { reference centres, lectures, tutorials, seminars, VLE, the Centre for Language } \\
\text { Study (CLS), libraries, on-line, print and computer-based resources, language } \\
\text { laboratories and satellite TV, self-access materials. }\end{array}$ \\
\hline $\begin{array}{l}\text { University of } \\
\text { Trento, } \\
\text { Italy }\end{array}$ & $\begin{array}{l}\text { Self-study methodology, monitored by the teacher, through the use of an online } \\
\text { interactive package of courses (the Macmillan English Campus or MEC), } \\
\text { updated resource bank, communication services (mostly via e-mail). }\end{array}$ \\
\hline
\end{tabular}

Table A2

North and Latin American blended learning cases: Support sources used in BL

\begin{tabular}{|l|l|}
\hline University & Resources \\
\hline USA & $\begin{array}{l}\text { Online course management systems, threaded discussions, chat } \\
\text { rooms, libraries, learning centres, tutoring and writing services, } \\
\text { web-based resources, interactive technology, including voiceover } \\
\text { PowerPoints, Skype, and YouTube videos. }\end{array}$ \\
\hline $\begin{array}{l}\text { The University of Florida, } \\
\text { USA }\end{array}$ & $\begin{array}{l}\text { English Language Institute (ELI), learning centres, course } \\
\text { management system, web-based resources, web conferencing } \\
\text { services, audio-visual and print-based materials, language tests, } \\
\text { proctored exams, MOOs, and chats. }\end{array}$ \\
\hline $\begin{array}{l}\text { University of Southern } \\
\text { USA }\end{array}$ & $\begin{array}{l}\text { Course management system, web-based resources, telephone and } \\
\text { web conferencing services, audio-visual and print-based materials, } \\
\text { information technology services, web publishing, web-casting } \\
\text { services, language labs, conversation groups, and libraries. }\end{array}$ \\
\hline $\begin{array}{l}\text { Universidad Nacional de } \\
\text { Colombia, }\end{array}$ & $\begin{array}{l}\text { Alex virtual program, F2F and videoconference sessions with the } \\
\text { instructor, interactive modules, follow-up self-access materials, } \\
\text { tutoring sessions, conversation clubs, literary café sessions, } \\
\text { placement and progress tests, self-access room (sala de auto- } \\
\text { acceso), LMS, IT support services. }\end{array}$ \\
\hline $\begin{array}{l}\text { Universidad de La Sabana, } \\
\text { Colombia }\end{array}$ & $\begin{array}{l}\text { LMS: Virtual Sabana, Blackboard Elluminate Live, help desk, } \\
\text { computer labs mobile workstations, physical and online library, } \\
\text { digital repositories, tutorial sessions, IT support, STUDIUM (self- } \\
\text { access centre), student language assistantships, conversation } \\
\text { clubs, tutoring sessions, proctored exams. }\end{array}$ \\
\hline $\begin{array}{l}\text { Universidad de Guadalajara } \\
\text { Mirtual, }\end{array}$ & $\begin{array}{l}\text { Web portal, virtual library, optional online courses and } \\
\text { conferences, computer services, self-access materials, access to } \\
\text { CASA Universitaria (learning communities and distance academic } \\
\text { services). }\end{array}$ \\
\hline $\begin{array}{l}\text { Course management system (Blackboard), tutoring sessions, } \\
\text { technology-based materials, Tutoriums, computer support (labs }\end{array}$ \\
\hline
\end{tabular}




\begin{tabular}{|l|l|}
\hline & $\begin{array}{l}\text { and technical team), library, custom online and F2F intensive } \\
\text { courses, proctored exams. }\end{array}$ \\
\hline $\begin{array}{l}\text { University of Calgary, } \\
\text { Canada }\end{array}$ & $\begin{array}{l}\text { Desire2learn platform, IT support, Adobe Connect, writing } \\
\text { support, mini-guides, online student handbooks, language labs, } \\
\text { Blackboard Elluminate Live platform, tutorial sessions, } \\
\text { independent- study online courses, e-portfolio resources, and } \\
\text { support services. }\end{array}$ \\
\hline $\begin{array}{l}\text { Athabasca University, } \\
\text { Canada }\end{array}$ & $\begin{array}{l}\text { Teleconferencing, videoconferencing, print and online materials, } \\
\text { e-mail, fax, internet assignment delivery modes, library and } \\
\text { research centres, help desk, information centre, advisor and } \\
\text { counsellor team services, exam services (exams to be taken at an } \\
\text { invigilated location), technology systems to support education: } \\
\text { Moodle, e-Portfolio, Mahara, Landing social networking site. }\end{array}$ \\
\hline
\end{tabular}

Table A3

Australian blended learning cases: Support sources used in $B L$

\begin{tabular}{|l|l|}
\hline University & Resources \\
\hline $\begin{array}{l}\text { Macquarie University, } \\
\text { Australia }\end{array}$ & $\begin{array}{l}\text { Online multimedia resources, IT help, Independent Learning Centre (ILC), } \\
\text { handbooks and tutorials, iLearn (the university's learning technologies } \\
\text { platform), Echo360 Lecture Recordings (formerly known as iLecture), } \\
\text { unit resources and readings (both print and web-based), LAMS, Wimba } \\
\text { Voice Tools, IT services. }\end{array}$ \\
\hline $\begin{array}{l}\text { University of New South } \\
\text { Wales, } \\
\text { Australia }\end{array}$ & $\begin{array}{l}\text { Library, technology-enabled learning and teaching platform (TELT), E- } \\
\text { Portfolio, virtual meeting rooms, varied, learning management systems, } \\
\text { webinars, recorded lectures, MOOCs. Two units support the development } \\
\text { of BL initiatives: Learning and Teaching Unit, and the COFA Online } \\
\text { gateway (academic unit responsible for the development and management } \\
\text { of a wide range of fully online and blended undergraduate and } \\
\text { postgraduate courses in art and design disciplines at the College of Fine } \\
\text { Arts [CoFA]). }\end{array}$ \\
\hline
\end{tabular}

Table A4

Asian blended learning cases Support sources used in BL

\begin{tabular}{|l|l|}
\hline University & Resources \\
\hline $\begin{array}{l}\text { Open University } \\
\text { Malaysia }\end{array}$ & $\begin{array}{l}\text { Open University Malaysia Learning Management, e-mail and other IT } \\
\text { services, access to library and laboratories, self-managed resources such as } \\
\text { podcasts and various audio visual materials, tutor instruction, CD-ROM } \\
\text { courseware, discussion forums, and diverse classroom environments } \\
\text { (formal classroom, computer lab, science lab). }\end{array}$ \\
\hline $\begin{array}{l}\text { Waseda University, } \\
\text { Japan }\end{array}$ & $\begin{array}{l}\text { On-demand lectures, joint classes with overseas universities, LMS, content } \\
\text { production studio, chat and video conference, CCDL (cross-cultural } \\
\text { distance learning) classes a distance exchange class session held with } \\
\text { overseas universities using video conference systems and chat systems), } \\
\text { Waseda University Open Courseware (OCW). }\end{array}$ \\
\hline
\end{tabular}

